\title{
Surgery and the Prevention of Plantar Ulcers
}

\author{
W. F. ROSS, M.B.B.S., D.T.M. \& H. \\ HUGH MACLEAN, M.G.S.P. \\ Oji River Leprosarium, E. Nigeria
}

\section{N T R ODUCTION}

Ulceration of the extremities in patients with nerve damage is almost invariably the result of unregarded trauma (RICHARIDS). In the foot the large majority of ulcers occur on the weight-bearing portions of the sole and are due to the trauma of walking. This is very much increased when the neuropathy is associated with established deformity. BRAND and his colleagues have shown that for example in cases of foot-drop the pressure under the head of the $5^{\text {th }}$ metatarsal may be increased to 2 or 3 times that in normal individuals. CLAWSON and SEDDON are of the opinion that deformity is a much more important cause of ulceration than anaesthesia. This opinion is entirely in accord with our experience and we find that in practically all cases the site of an ulcer is determined by the presence of static or dynamic deformity. In many individuals the points of increased

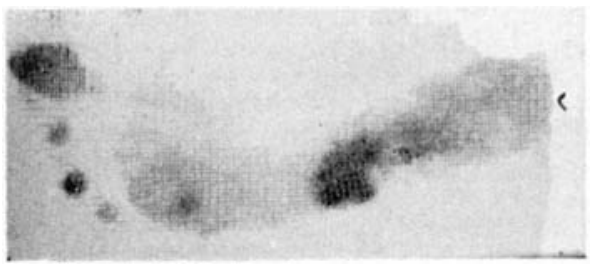

FIti. I. Walking footprint of a patient with gross inversion.

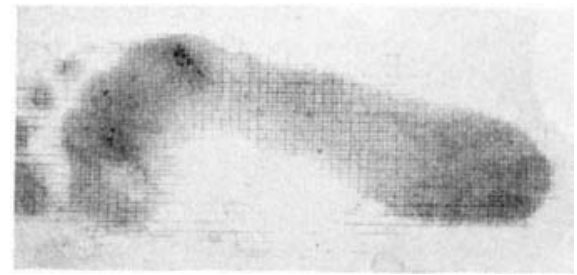

FIc. 2. Walking footprint of a patient who subsequently developed ulceration under the and metatarsal head.

trauma on these anaesthetic and deformed feet is obvious on inspection as for example in an inverted foot it is quite clear that the maximum trauma is occurring at the lateral border of the foot (Fig. I). In other cases points of maximum trauma are not so obvious but can be discovered by means of a walking footprint. In many instances the use of this device enables the surgeon to predict the point at which ulceration will occur unless preventive measures are taken. Some of our patients have not accepted the necessity for such measures and we have seen ulcers develop at the expected sites (Fig. 2). It is not always appreciated that a dynamic deformity, due to muscle imbalance, is just as important a factor in causation of ulceration as is fixed deformity. Dynamic deformity cannot always be detected by inspection of the foot but are quite easily revealed by the walking footprint. Further, if the patient has been walking in shoes the pattern of wear on the insole is often a valuable indicator of the site of danger points. 
There is no doubt that footwear for these deformed feet is of very great value (PRICE, ROSs, and WARD) but it secms reasonable to say that in addition to providing suitable footwear, deformity should be corrected surgically wherever it is possible. 'This has the great advantage that when once the deformity has been corrected we find that ulceration can be prevented in many cases by relatively simple and incxpensive footwear. In addition many cases of gross deformity for whom footwear alone is not effective can be helped by a combination of judicious surgery and suitable footwear. Surgery is not to be undertaken lightly and should be part only of a co-ordinated plan to obtain a weight-bearing foot.

\section{METHODS}

At this institution $55^{102}$ patients with plantar uleers were admitted for

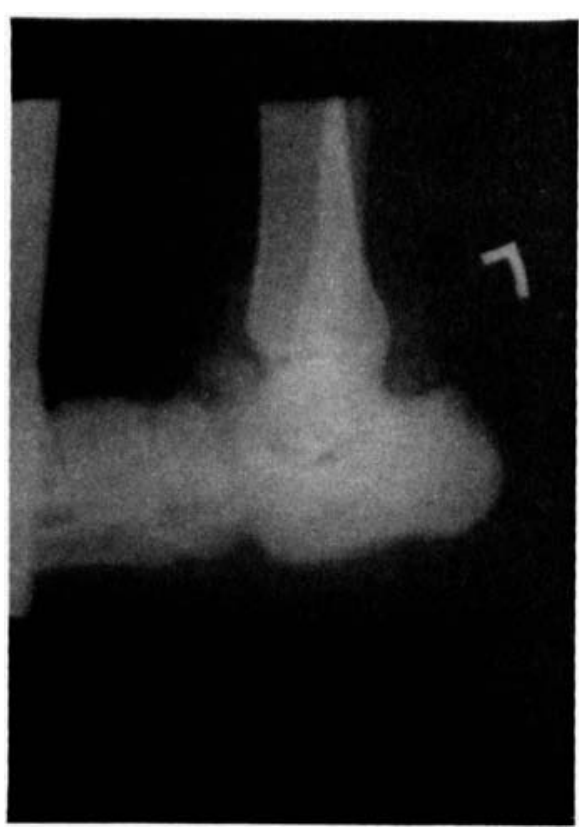

FIG. 3. X-ray showing disintegration of mid-tarsal bones after tibialis posterior transplantation. treatment during the years ${ }_{9} 6_{1}-62$. Following the healing of the ulcers $5^{8}$ of the patients were subjected to 76 operations designed to prevent recurrence of the ulceration (from these Io below-knec amputations and 4 amputations of the great toe are not included in this study). Fortythree of the cases have been followedup and re-examined in June and July this year. 'The followed-up cases had had 53 operations. Account has also been taken of 69 similar procedures done in the years $1963-64$ and of 33 operations for the correction of footdrop and I 3 for correction of invertion of the foot carried out on leprosy patients who have never had ulceration. One of the cases of foot-drop developed metatarsal disintegration following foot-drop correction (Fig. 3).

In all cases an attempt has been made to ascertain the time at which ulceration of the foot first occurred and to discover in broad outline the subsequent history of the foot. Records of all patients who have been treated here from January I959 onwards are available and have been consulted. The methods used for pre- and post-operative assessment of patients have been described in Chapter 29 of Leprosy in Theory and Practice, I 964, 2nd edition, by R. G. Cochrane and T. F. DAVEy. These include tests for anaesthesia and paralysis, the taking of a walking foot-print and a recording of the general texture of the skin of the sole and the presence or absence of haematomata, scars, callosities, fungus infection and open 
wounds. Clawing of the toes and other deformities are also noted and records made of the range of movement in the ankle joint and of abnormalities detected clinically in the tarsal and mid-tarsal joints. An X-ray plant has been available for the past 6 months and all cases included in the study had standard anterior-posterior, lateral and oblique views taken of the foot (HARRIS and вЕAтH).

\section{Sec Table I.}

RES ULTS

'This analysis is concerned only with surgery and no attempt has been made to discuss why footwear failed to control ulcers in the cases who had it.

D)uring $1961 / 62$ approximately $\mathrm{I}$ in 8 of the patients admitted for uker treatment had surgery subsequently. 'This proportion has now risen but no patient is subjected to surgery if it is felt that footwear alone has a good chance of preventing re-ulceration.

In 33 feet the operations have been completely successful. In I $_{5}$ there has been failure or partial failure post operatively and in one the foot became gangrenous and had to be amputated.

Nine of the failures were undoubtedly due to inadequate excision of bone, resulting in weight bearing on scarred skin post operatively, 6 including the case (44) which became gangrenous were due to wrong choice of operation and one patient (29) should not have been operated upon at all.

(a) Cases with tibialis posterior transplant (I I). Cases ( $\mathrm{I}-\mathrm{I}(0)$.

Seven out of the I I cases of tibialis posterior transplant have been completely ulcer free since the operation. 'The 4 ulcers which have occurred have all been small. (One was due to failure to balance up the foot as a result of using a procedure involving tendon anastomosis which has now been given up (case 5), and one was due to failure to line up the stumps accurately during forefoot amputation (case 8). The ulcer in case (3) could perhaps have been avoided if a subtaloid arthrodesis had been done as well as the tibialis posterior transplant, and the feet in case ( 10$)$ are so badly scarred that the fact that the patient has only had one ulcer is a pleasant surprise.

(b) Cases with triple arthrodesis (7). (Cases 8, I I, I3-18.)

'l'wo of these cases should have had amputation as a primary procedure (cases i I and I 3 ) as the feet were so scarred that it was impossible to relieve the scarred tissue of weight bearing. In two cases the bone resection was inadequate (cases 17 and 18 ) and threc cases have been completely successful (cases 14,15 and 16 ).

(c) Cases with wedge resection of the ankle joint (4 patients).

'I'wo of these cases were failures. Case (12) has subsequently had an amputation and case (30) was recommended for an amputation in 1959 and refused. Cases (28) and (20) have been completely ulcer free since the operation.

(d) Cases with foref oot amputation (9).

Six out of the 9 cases are ulcer free, i.e. cases $(4,23 a, 25,26$ and $27 a$ and $b)$.

'Two of the failures (case 8 and 24) are due to inadequate excision of bone with the result that scarred tissue continues to bear weight and I (case 23b) is due to surgical intervention in the presence of infection.

(e) Cases with metatarsal head resection (4).

'Two of the cases (42 and 43) have not re-ulcerated and two (40) and 41 ) have. The two failures were due to failure to line up the metatarsal stumps at operation, with the result that the more prominent stumps bore too much weight. 


\begin{tabular}{|c|c|c|c|c|c|c|c|c|c|c|}
\hline $\begin{array}{l}\text { Case } \\
\text { No. }\end{array}$ & $\begin{array}{l}\text { Duration } \\
\text { of L'lcers } \\
\text { minimum } \\
\text { yr. }\end{array}$ & $\begin{array}{l}\text { Principal } \\
\text { Sites of } \\
\text { L'lcers }\end{array}$ & $\begin{array}{l}\text { Shoes } \\
\text { Pre-op. }\end{array}$ & Operation & Date & $\begin{array}{l}\text { Shoes } \\
\text { Post-op. }\end{array}$ & $\begin{array}{l}\text { Date of } \\
\text { Llcers } \\
\text { Post-op. }\end{array}$ & $\begin{array}{l}\text { Site of } \\
\text { Post-op. } \\
\text { L'lcer }\end{array}$ & Comments & Results \\
\hline I & $\bar{j}$ & $\begin{array}{l}\text { M.H.3, } \\
\text { mid-sole }\end{array}$ & - & $\begin{array}{l}\text { Tibialis } \\
\text { Posterior } \\
\text { Transplant }\end{array}$ & $8: 62$ & $\begin{array}{l}\text { Micro- } \\
\text { cellular } \\
\text { rubber shoes }\end{array}$ & - & 一 & & $\mathrm{S}$ \\
\hline 2 & 5 & $\begin{array}{l}\text { M.H.3, } \\
\text { toe-tips }\end{array}$ & 一 & , & $5: 6$ I & " & - & - & & $\mathrm{S}$ \\
\hline 3 & $5+$ & $\begin{array}{l}\text { M. Heads } \\
\text { mid-lat. }\end{array}$ & $\begin{array}{l}\text { Wood } \\
\text { shoes }\end{array}$ & , & I $2: 62$ & $"$ & 63 & Mid-lat. & $\begin{array}{l}\text { Small dry ulcer. } \\
\text { Foot not deteriorating }\end{array}$ & $\mathrm{S}$ \\
\hline & $5+$ & $\begin{array}{l}\text { M. Heads } \\
\text { mid-lat. }\end{array}$ & , & , & $4: 1: 63$ & $"$ & - & - & & $\mathrm{S}$ \\
\hline 4 & $5+$ & $\begin{array}{l}\text { M.H.ı, M.H.2 } \\
\text { mid-sole }\end{array}$ & , & $\begin{array}{l}\text { Fore-foot } \\
\text { amputation } \\
+ \text { tib-post. } \\
\text { transplant }\end{array}$ & $\begin{array}{l}3: 6 \text { I } \\
\text { I } 2: 62\end{array}$ & " & - & - & & $\mathrm{S}$ \\
\hline 5 & 4 & $\begin{array}{l}\text { P.P.H., } \\
\text { M.HI. }\end{array}$ & M.C.R. & $\begin{array}{l}\text { Tib.-post. } \\
\text { transplant }\end{array}$ & I :62 & $"$ " & 63 & M.H. 2 & $\begin{array}{l}\text { Inversion accentuated } \\
\text { post-op. } \\
\text { Tendon anastomosis done }\end{array}$ & $\mathrm{F}$ \\
\hline 6 & 4 & M.H.j & , & , & $7: 6 \mathrm{I}$ & $"$ & - & - & & $\mathrm{S}$ \\
\hline 7 & 3 & $\begin{array}{l}\text { M.H.5 } \\
\text { lat. sole }\end{array}$ & , & , & $4: 62$ & , & $=$ & - & & $\mathrm{S}$ \\
\hline 8 & $3+$ & M.H. I-j & , & $\begin{array}{l}\text { Fore-foot } \\
\text { amputation } \\
\text { Tib.-post } \\
\text { transplant } \\
\text { Sub-taloid } \\
\text { arthro' }\end{array}$ & $\begin{array}{l}3: 62 \\
\text { I I :62 } \\
5: 62\end{array}$ & $n$ & $6 t$ & M.H.3 & $\begin{array}{l}\text { 1 } 8 / 12 \text { post-op. small ulcer } \\
\text { due to inadequate excision } \\
\text { of } \mathbf{M} . \mathrm{H} .3\end{array}$ & $\mathrm{~F}$ \\
\hline 9 & $3+$ & $\begin{array}{l}\text { Mid sole } \\
\text { M.H.3 heel }\end{array}$ & Cilogs & $\begin{array}{l}\text { Tib.-post } \\
\text { transplant }\end{array}$ & $6: 62$ & " & - & - & & $\mathrm{S}$ \\
\hline
\end{tabular}




\begin{tabular}{|c|c|c|c|c|c|c|c|c|c|c|}
\hline $\begin{array}{l}\text { Case } \\
\text { No. }\end{array}$ & $\begin{array}{l}\text { Duration } \\
\text { of Clcers } \\
\text { minimum } \\
\text { yr. }\end{array}$ & $\begin{array}{l}\text { Principal } \\
\text { Sites of } \\
\text { Lilcers }\end{array}$ & $\begin{array}{l}\text { Shoes } \\
\text { Pre-op. }\end{array}$ & Operation & Date & $\begin{array}{l}\text { Shoes } \\
\text { Post-op. }\end{array}$ & $\begin{array}{l}\text { Date of } \\
\text { Llcers } \\
\text { Post-op. }\end{array}$ & $\begin{array}{l}\text { Site of } \\
\text { Post-op. } \\
\text { Llcer }\end{array}$ & Comments & Results \\
\hline \multirow[t]{2}{*}{ IO } & $10+$ & $\begin{array}{l}\text { M. Heads } \\
\text { Toes }\end{array}$ & Clogs & $\begin{array}{l}\text { Tib.-post } \\
\text { transplant }\end{array}$ & $5: 61$ & $\begin{array}{l}\text { M.C.R. } \\
\text { shoes }\end{array}$ & - & - & $\int \begin{array}{l}\text { These feet are } \\
\text { very short }\end{array}$ & e $S$ \\
\hline & Io+ & , & $"$ & , & $5: 61$ & ", & 64 & Mid-lat. & $\begin{array}{l}\text { Small dry } \\
\text { ulcer }\end{array} \quad \begin{array}{l}\text { with gross } \\
\text { M.H. damage }\end{array}$ & $e^{S}$ \\
\hline I I & $5+$ & $\begin{array}{l}\text { M. Heads } \\
\text { Toes } \\
\text { Mid-lat. }\end{array}$ & $\begin{array}{l}\text { Clogs and } \\
\text { M.C.R. }\end{array}$ & $\begin{array}{l}\text { Triple } \\
\text { arthrodesis }\end{array}$ & $6: 6$ I & , & $6 \mathrm{I}$ & Mid-lat. & \multirow{2}{*}{$\begin{array}{l}\text { This foot was grossly } \\
\text { scarred and the pro- } \\
\text { cedures failed to relieve } \\
\text { scar of weight bearing } \\
\text { (Same patient as I I ) } \\
\text { This foot was grossly } \\
\text { scarred and the procedures } \\
\text { failed to relieve scar of } \\
\text { weight bearing }\end{array}$} & F \\
\hline 12 & $5+$ & $\begin{array}{l}\text { M. Heads } \\
\text { Toes } \\
\text { Mid-lat. }\end{array}$ & M.C.R. & $\begin{array}{l}\text { Wedge } \\
\text { osteotomy }\end{array}$ & $9: 62$ & , & 62 & Mid-lat. & & $\mathrm{F}$ \\
\hline I 3 & $5+$ & $\begin{array}{l}\text { Heel and } \\
\text { mid-lat. }\end{array}$ & $\begin{array}{l}\text { Wood } \\
\text { shoe }\end{array}$ & $\begin{array}{l}\text { Triple } \\
\text { arthrodesis }\end{array}$ & $9: 62$ & , & 63 & Mid-lat. & , & $\mathrm{F}$ \\
\hline 14 & 3 & Mid-lat. & - & $\begin{array}{l}\text { Triple } \\
\text { arthrodesis } \\
+ \text { tib.post. } \\
\text { transplant }\end{array}$ & $\begin{array}{l}\text { I } 1: 62 \\
8: 63\end{array}$ & $"$, & - & - & I I / 2 follow up & $\mathrm{S}$ \\
\hline I 5 & $5+$ & , & M.C.R. & $\begin{array}{l}\text { Triple } \\
\text { arthrodesis }\end{array}$ & I $2: 62$ & ", & 64 & $\begin{array}{l}\text { Lat. } \\
\text { border }\end{array}$ & $\begin{array}{l}\text { Uilcer not on weight } \\
\text { bearing surface. Due to } \\
\text { shoe strap }\end{array}$ & $\mathrm{S}$ \\
\hline I 6 & 5 & $\begin{array}{l}\text { M. Heads } \\
\text { Toes }\end{array}$ & - & ", & $4: 62$ & , & 一 & - & $\begin{array}{l}\text { Anterior wedge to } \\
\text { correct equinus }\end{array}$ & $\mathrm{S}$ \\
\hline 17 & $5+$ & Mid-lat. & Clogs & ", & $12: 62$ & $"$ & 63 & Mid-lat. & Inadequate lateral wedge & $\mathrm{F}$ \\
\hline I 8 & 5 & $\begin{array}{l}\text { M.H.2 and } 3 \\
\text { mid-lat. }\end{array}$ & - & ", & I $0: 62$ & ", & 63 & , &, & $\mathbf{F}$ \\
\hline I9 & 4 & M.H. I and 5 & - & $\begin{array}{l}\text { MHI excised } \\
\text { Toe } 2-5 \text { claw } \\
\text { corrected }\end{array}$ & $\begin{array}{l}61 \\
8: 62\end{array}$ & ", & $\overline{63}$ & $\overline{\text { Toe tips }}$ & Lilcers due to burns & $\mathrm{S}$ \\
\hline
\end{tabular}




\begin{tabular}{|c|c|c|c|c|c|c|c|c|c|c|}
\hline $\begin{array}{l}\text { Case } \\
\text { No. }\end{array}$ & $\begin{array}{l}\text { Duration } \\
\text { of Ulcers } \\
\text { minimum } \\
\text { yr. }\end{array}$ & $\begin{array}{l}\text { Principal } \\
\text { Sites of } \\
\text { Ulcers }\end{array}$ & $\begin{array}{l}\text { Shoes } \\
\text { Pre-op. }\end{array}$ & Operation & Date & $\begin{array}{l}\text { Shoes } \\
\text { Post-op. }\end{array}$ & $\begin{array}{l}\text { Date of } \\
\text { Ulcers } \\
\text { Post-op. }\end{array}$ & $\begin{array}{l}\text { Site of } \\
\text { Post-op. } \\
\text { Ulcer }\end{array}$ & Comments & Results \\
\hline 20 & 3 & $\begin{array}{l}\text { P.P.H. and } \\
\text { M.H.I }\end{array}$ & M.C.R. & $\begin{array}{l}\text { Claw toe } \\
\text { correction } \mathrm{I}-5\end{array}$ & $4: 6$ I & M.C.R. & 一 & - & & $\mathrm{S}$ \\
\hline 21 & 2 & M.H.5 & , & $\begin{array}{l}\text { Claw toe } \\
\text { correction } \mathrm{I}-4 \\
\text { Excision M.H.5 }\end{array}$ & I $2: 62$ & , & 一 & - & $\begin{array}{l}\text { Slight decrease in depth } \\
\text { of anaesthesia by June } 64\end{array}$ & $\mathrm{~S}$ \\
\hline 22 & 5 & M.H.4 & - & $\begin{array}{l}\text { DuVries } \\
\text { M.H.4 }\end{array}$ & 1 $0: 62$ & , & - & - & & $\mathbf{S}$ \\
\hline \multirow[t]{2}{*}{23} & 4 & $\begin{array}{l}\text { M.H.2, 3, } 4 \\
\text { and } 5\end{array}$ & - & $\begin{array}{l}\text { Fore foot } \\
\text { amputation }\end{array}$ & $7: 6$ I & " & - & - & . & $\mathrm{S}$ \\
\hline & 4 & M.H.2, 3, 4 & - & $\eta$ & $7: 61$ & , & 62 & Dorsum & $\begin{array}{l}\text { Operations done in pre- } \\
\text { sence of ulcers. Small } \\
\text { portion of wound did not } \\
\text { heal satisfactorily }\end{array}$ & $\mathbf{F}$ \\
\hline 24 & 5 & M.H.2, 3 & $\begin{array}{l}\text { Wood } \\
\text { shoe }\end{array}$ & ," & $6: 62$ & , & I $0: 63$ & M.H.3 & $\begin{array}{l}\text { Amputation too con- } \\
\text { servative }\end{array}$ & $\mathbf{F}$ \\
\hline 25 & 4 & Mid M.H. & Clog & $\begin{array}{l}\text { Fore foot } \\
\text { amputation }\end{array}$ & I $2: 62$ & , & - & - & & $\mathbf{S}$ \\
\hline 26 & $2+$ & M. Heads & ", & . $\quad$, & $2: 62$ & " & - & - & & $\mathrm{S}$ \\
\hline \multirow[t]{2}{*}{27} & I I & M.H.2, 34 & " & $"$ & $9: 62$ & , & - & - & & $\mathrm{S}$ \\
\hline & I I & M.H.1, 2, 3, 4 & , &, & $9: 62$ & , & - & - & & $\mathbf{S}$ \\
\hline 28 & $5+$ & $\begin{array}{l}\text { Mid-lat., M. } \\
\text { Heads and toes }\end{array}$ & ", & $\begin{array}{l}\text { Wedge } \\
\text { osteotomy ankle }\end{array}$ & $e^{7: 62}$ &, & - & - & Grossly deformed foot & $\mathbf{S}$ \\
\hline 29 & $5+$ & Forefoot & $"$ & $\begin{array}{l}\text { Wedge } \\
\text { resection }\end{array}$ & $8: 62$ & , & - & - & $\begin{array}{l}\text { Equinus remains fixed } \\
\text { at } 100^{\circ}\end{array}$ & $\mathbf{S}$ \\
\hline 30 & $\mathrm{IO}+$ & Mid-lat. & $\begin{array}{l}\text { Wood } \\
\text { shoe }\end{array}$ & , & $9: 62$ & ", & $5: 63$ & $\begin{array}{l}\text { Lt. mid- } \\
\text { lat. }\end{array}$ & $\begin{array}{l}\text { Amputation recommended } \\
\text { in I } 959 \text { and refused by } \\
\text { patient }\end{array}$ & $\mathbf{F}$ \\
\hline $3^{1}$ & $5+$ & Heel & - & $\begin{array}{l}\text { Ankle fusion } \\
\text { for Chârcot } \\
\text { joint }\end{array}$ & $6: 62$ & , & - & - & $\begin{array}{l}\text { No ulcers but fusion has } \\
\text { completely broken down }\end{array}$ & $\mathbf{F}$ \\
\hline
\end{tabular}


TABLE I-continued

\begin{tabular}{|c|c|c|c|c|c|c|c|c|c|c|}
\hline $\begin{array}{l}\text { Case } \\
\text { No. }\end{array}$ & $\begin{array}{l}\text { Duration } \\
\text { of Ulcers } \\
\text { minimum } \\
\text { yr. }\end{array}$ & $\begin{array}{l}\text { Principal } \\
\text { Sites of } \\
\text { Ulcers }\end{array}$ & $\begin{array}{l}\text { Shoes } \\
\text { Pre-op. }\end{array}$ & Operation & Date & $\begin{array}{l}\text { Shoes } \\
\text { Post-op. }\end{array}$ & $\begin{array}{l}\text { Date of } \\
\text { Ulcers } \\
\text { Post-op. }\end{array}$ & $\begin{array}{l}\text { Site of } \\
\text { Post-op. } \\
\text { Clcer }\end{array}$ & Comments & Results \\
\hline 32 & 2 & Toe tips & Clog & $\begin{array}{l}\text { I.P. } \\
\text { arthrodesis }\end{array}$ & $7: 62$ & MI.C.R. & - & - & & $\mathbf{S}$ \\
\hline 33 & 3 & M.H.2, 3, 4, 5 & 一 & $\begin{array}{l}\text { I.P. } \\
\text { arthrodesis } \\
\text { Ex. to M.H. } \\
\text { heads }\end{array}$ & $7: 62$ & $"$ & 一 & - & & $\mathbf{S}$ \\
\hline 34 & 2 & $\begin{array}{l}\text { Toe tips } \\
\text { M.H.I }\end{array}$ & - & $\begin{array}{l}\text { I.P. } \\
\text { arthrodesis } \\
\text { Hallux } \\
2-5 \text { extensors } \\
\text { to M. Heads }\end{array}$ & $5: 62$ & $"$ & - & 一 & & $\mathrm{S}$ \\
\hline 35 & 10 & M. Heads & - & $\begin{array}{l}\text { Extensors to } \\
\text { heads I and } 2\end{array}$ & $4: 62$ & , & - & - & & $\mathrm{S}$ \\
\hline 36 & 9 & M.H.2 & Clog & $\begin{array}{l}\text { Excision } \\
\text { P.P. toe } 2\end{array}$ & $3: 62$ & , & 一 & - & $\begin{array}{l}\text { Previous division of ex- } \\
\text { tensor tendons to relieve } \\
\text { clawing failed }\end{array}$ & $\mathbf{S}$ \\
\hline 37 & 6 & Heel & 一 & Split heel & 10:62 & $\begin{array}{l}\text { Special } \\
\text { shoe }\end{array}$ & 63 & Heel & $\begin{array}{l}\text { Pre-op. scar fixed to } \\
\text { calcaneum }\end{array}$ & $\mathrm{F}$ \\
\hline 38 & 5 & M.H.2, 3, 4, 5 & Clog & $\begin{array}{l}\text { Tendo-Achilles } \\
\text { lengthening }\end{array}$ & $10: 62$ & M.C.R. & $3: 64$ & $\begin{array}{l}\text { M.H.I } \\
\text { and } 3\end{array}$ & & $\mathrm{~F}$ \\
\hline 39 & 3 & M.H.5 & M.C.R. & $\begin{array}{l}\text { Tib. ant. } \\
\text { transplant }\end{array}$ & $7: 62$ & , & - & - & $\begin{array}{l}\mathrm{M} . \mathrm{H} .5 \text { excised previously } \\
\text { but this failed to prevent } \\
\text { reulceration }\end{array}$ & $\mathbf{S}$ \\
\hline 40 & 5 & M.H. I, 2 and & $\begin{array}{l}\text { Wood } \\
\text { shoe }\end{array}$ & $\begin{array}{l}\text { Excision meta- } \\
\text { tarsal heads }\end{array}$ & I $2: 62$ & ", & I $0: 63$ & M.H.4 & $\begin{array}{l}\text { Excision of metatarsal } \\
\text { inadequate }\end{array}$ & $\mathrm{F}$ \\
\hline $4^{I}$ & 8 & Mid M. heads &, & , & $7: 62$ & , & $4: 64$ & M.H.2 & Excision $\mathrm{H} .2$ inadequate & $\mathrm{F}$ \\
\hline $4^{2}$ & 4 & , & Clog & " & I $2: 62$ & $"$ & - & - & & $\mathrm{S}$ \\
\hline 43 & 5 & , &, & , & $6: 62$ & , & - & - & & $\mathrm{S}$ \\
\hline 44 & $10+$ & $\begin{array}{l}\text { Mid-lat. M. } \\
\text { Heads Toes }\end{array}$ & $\begin{array}{l}\text { Wood } \\
\text { shoe }\end{array}$ & $\begin{array}{l}\text { Astraga- } \\
\text { lectomy }\end{array}$ & I $2: 62$ & - & - & 一 & $\begin{array}{l}\text { Foot became gangrenous } \\
\text { and was amputated }\end{array}$ & $\mathrm{F}$ \\
\hline
\end{tabular}


(f) Claw toe corrections.

I. Interphalangeal joint arthrodesis (3).

One case (32) had arthrodesis alone, one (33) had arthrodesis combined with transplantation of the long extensor tendons into the metatarsal heads, and one (34) had arthrodesis of the hallux combined with transplant of the long extensors. All were successful.

11. Extensor tendon transposition (3).

In addition to cases (33 and 34 ) which had extensor transplant plus arthrodesis, one case $\left(3^{2}\right)$ had the extensors of first and second toes transposed into the metatarsal heads. No further ulcers have occurred.

III. Excision of proximal phalanges.

In case ( 36$)$ the P.P. of toe 2 was excised, and the patient has had no further ulc ers.

Iv. Flexor tendon transposition (3).

None of these cases has had an ulcer post-operatively; in case (19) the transplant was combined with excision of the ist M.H., and in case (21) with excision of M.H.5.

v. Duvries operation (Fig. 20)

The single case (22) was successful.

(g) Split heel (1). Case (37).

Failed. T'he patient has subsequently had a long leg amputation using the dorsal skin of the foot to cover the stump, the stump is not suitable for weight bearing.

(h) 'T'endo achilles lengthening ( 1 ). Case (.38).

Failed. 'The patient has no equinus nor foot drop, but the forefoot is very badlyscarred, he is now ulcer free in a shoe with a metatarsal bar.

(i) T'ibialis anterior transposition (1). Case (39).

'This patient had peroneal palsy only, with the foot inverted. 'Transplant of the tibialis anterior to the lateral side of the foot has provided an adequate correction.

(j) Astragalectomy ( 1). Case (47).

'This operation was attempted through an anterior incision. 'The foot became gangrenous. The procedure has been abandoned in favour of lateral wedge resection.

\section{Pre-operative Cionsiderations}

C:ONCLUSIONS AND REC:OMMENDATIONS

No corrective surgery should be undertaken in the presence of infection or of infected wounds. The first step is, therefore, to heal any ulcers and clear up fungus infection. Surgery has a relatively small part to play in the treatment of ulcers and the application of a plaster of Paris cast after carrying out wound toilet remains the basic method of treatment. In our experience wounds heal more quickly if plaster of Paris casting can be supplemented by bed rest, but this is not essential. It is prudent to wait for one month after all wounds have healed before undertaking surgery of the fore-foot and at least 3 months before operations on the mid-foot and hind-foot are carried out. If it occurs, operative infection is at the worst disastrous leading to gangrene of the extremity and at the best, delays healing much longer than the 4 weeks or 12 weeks recommended above. As a rule there is no urgency about operations for the correction of footdrop and in these cases it is reasonable to wait until at least 6 months have passed after the foot-drop has occurred as with suitable medical care many 
cases of early foot-drop) recover. Surgery for deformity causing ulceration is a matter of urgency and should be carried out whatever the stage of the patient's general treatment. If reactions occur they can be treated in the usual manner.

\section{Cieneral Surgical Technique}

Surgery of the foot does not as a rule require such delicate techniques as surgery of the hand but, of course, if good results are to be achieved, just as much care and attention to detail is required in foot surgery as in hand surgery. A bloodless ficld is essential and a pneumatic tourniquet should be used. A pressure of $280 \mathrm{~mm}$. of mercury is adequate and should not be exceeded and it is probably wise not to keep the tomiquet applied for more than I hour at a time. 'This is because the operation may precipitate neuritis and in addition, many of these operations are taking place in feet potentially infected and the shorter the period of hacmostatis the better. If at the time of operation, when incisions are being made through previously ulcerated tissue, as for example when metatarsal heads are being excised, the tissues are found to be ocdematous or show other signs of decp infection, the wounds should be left unsutured. These wounds may subsequently be sutured as a delayed procedure or suturing omitted altogether. Such open wounds heal well if properly immobilized but if infected tissuc is sutured sloughing invariably occurs. Pressure bandages should not be used post-operatively as these may lead to superficial skin necrosis or even deep necrosis in certain cases. All operated limbs should be immobilized in padded non-weight bearing plaster of Paris casts. 'The toes should be left open to inspection in every case and the limb elevated for 48 hours post-operatively. After 48 hours if there is no ocdema or pain ambulation with crutches may be permitted.

\section{Post-operative Ciare}

In most neuropathic limbs response to trauma is good and healing takes place at the normal rate so that skin sutures can be removed after the normal period of Io days and parts subjected to tendon transplantation and arthrodesis immobilized for 4 to 6 weeks for tendon transplants and I o to I 6 weeks for arthrodeses. In patients with neuropathic bonc changes, however, fusion is extremely difficult to achieve and surgery is not recommended as a method of dealing with this problem. All cases must be provided with suitable footwear immediately post-operatively. 'The deformities amendable to surgery are only one factor of many in the etiology of ulcers and unless facilities are available for the provision of footwear surgery is better not undertaken.

\section{Common Deformities and their Corrections}

I. Deformities due to paralysis of the lateral popliteal nerve. 'This nerve supplies all the muscles which dorsiflex and evert the foot and which dorsiflex the toes. It also supplies one of the muscles which can invert the 


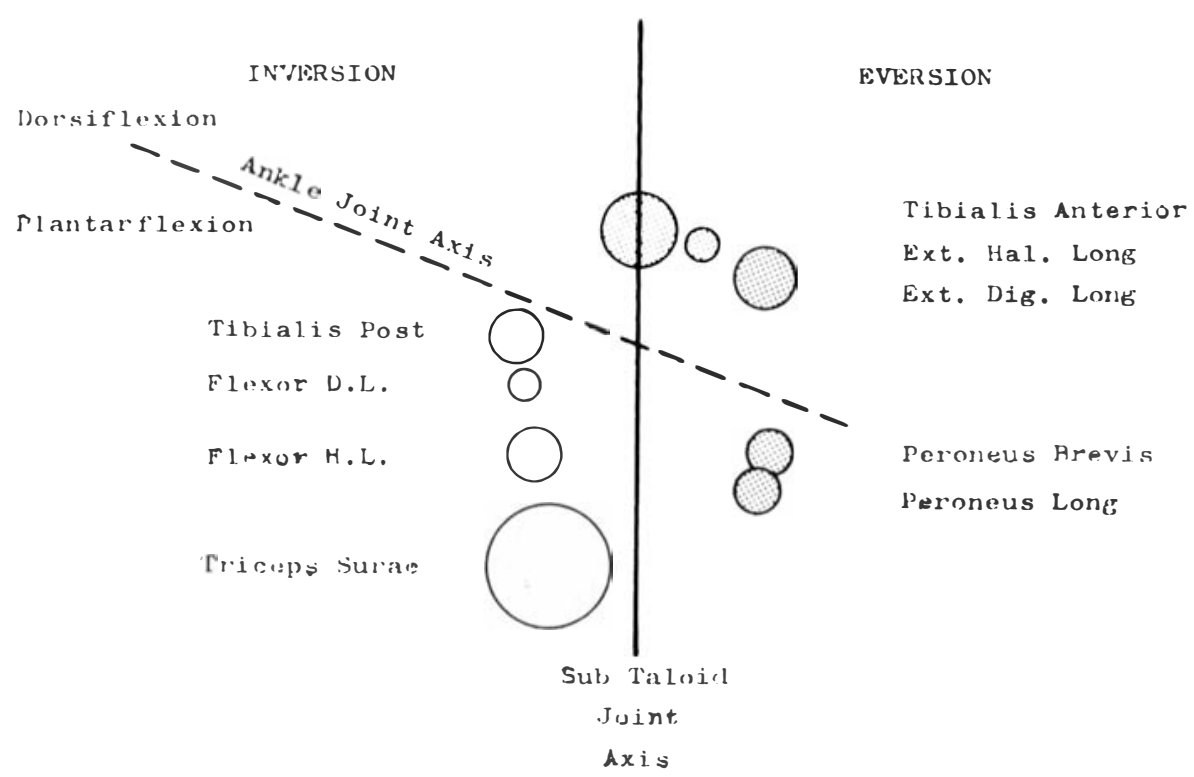

FIG. 4. Muscular control of the ankle joints. 'The muscles are represented by circles that have an area proportional to the physiologic cross section of the muscle. 'The position of the circles represents measurements of their lever arms with respect to the joint axes. Muscles marked are inncrvated by the lateral popliteal nerve. (From Elftman H. 'T'he 'I'ransverse 'T'arsal Joint and its Control'. Clinical Orlhopaedics, 16, 4 I-44.)

foot and a plantar (lexor of the first ray (Fig. 4). In leprosy these muscles may be completely paralysed or not paralysed at all or different muscles in the group may be affected to different degrees. Two stable patterns of paralysis are seen (a) complete paralysis, and (b) paralysis of lateral compartment muscles only. 'The former is by far the most common. We have seen 78 cases of complete foot-drop, 18 of them bi-lateral and only 6 cases of lateral compartment paralysis, 2 of them bi-lateral. None of the cases of lateral compartment paralysis escaped destructive ulceration. Sixty-four of the legs with complete foot-drop were of over 6 months duration when first seen. In only I of these did recovery occur and this patient had had the paralysis for 9 months. Thirty-seven of the feet showed gross secondary deformity of various sorts. These included 9 cases with neuropathic changes in the mid-tarsus, 9 cases with gross damage to the toes, and 23 cases with gross damage to toes and metatarsal heads; 6 of the latter had fixed equinous deformity also. Twenty-six of the late cases with complete foot-drop had minimal secondary deformity. Fifteen of them had never had ulceration and these included one bi-lateral case who claimed to have had the foot-drop for 20 years. All cxcept 4 of the cases had an associated anaesthesia of the sole of the foot. Of the I I cases who had had ulcers 4 had ulceration of the tips of the toes, 4 ulceration under the proximal phalanx of the hallux; one ulceration under the $5^{\text {th }}$ metatarsal head and one ulceration under the $5^{\text {th }}$ metatarsal base, and I case had ulceration under the middle metatarsal head. Of the 23 legs 
seen within 6 months of the foot-drop developing 14 recovered under medical treatment.

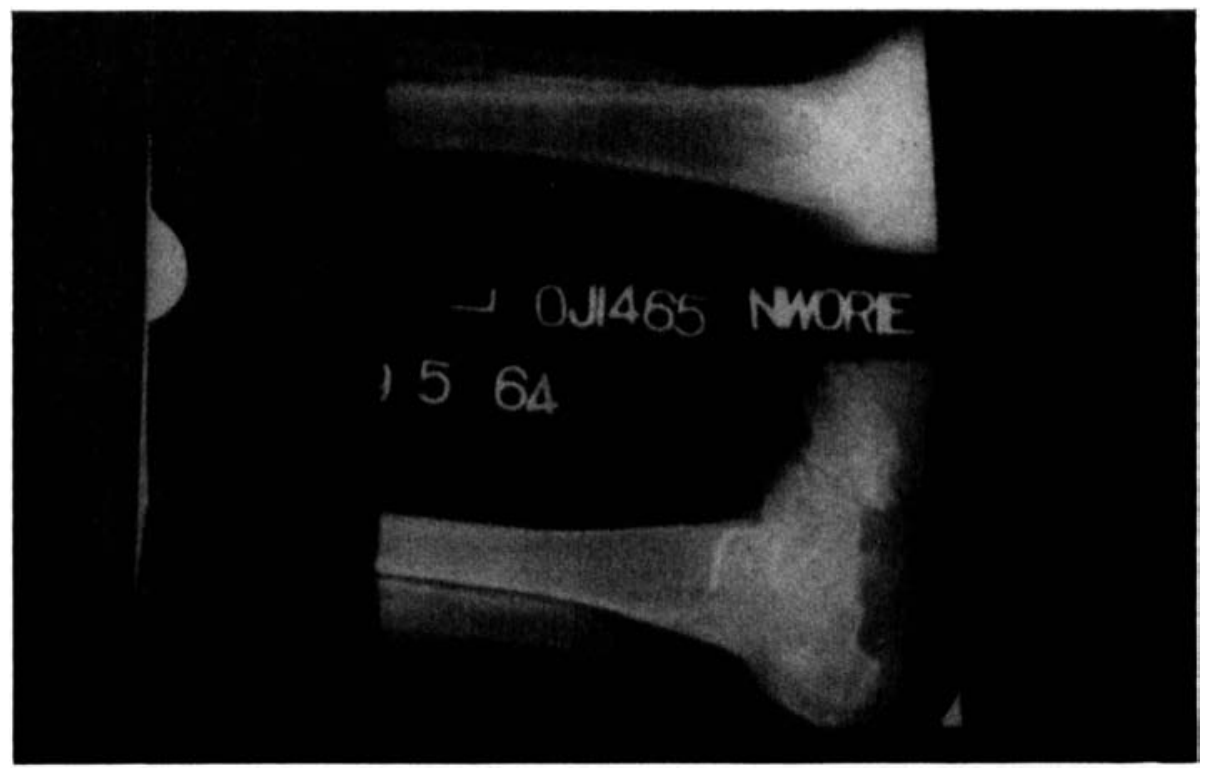

FIG. 5. X-ray of a patient who has had wedge resection of the ankle joint (case 28).

There is, therefore, sufficient evidence to say that if left to themselves feet with paralysis in the lateral compartment are in danger of developing gross ulceration sooner or later and the inversion deformity must be corrected. In early cases the inversion may be corrected by tibialis posterior transplantation but if there is any degree of fixed inversion subtaloid arthrodesis followed by tibialis posterior transplantation is required. Late cases commonly need lateral wedge resection or amputation (Fig. 5).

More than half the cases of complete foot-drop also develop gross ulceration in time. Many of these can be corrected by tibialis posterior transplantation and tendon achilles lengthening alone. 'Those with fixed inversion require subtaloid arthrodesis also, as do the cases with a fixed equinous (Fig. 6).
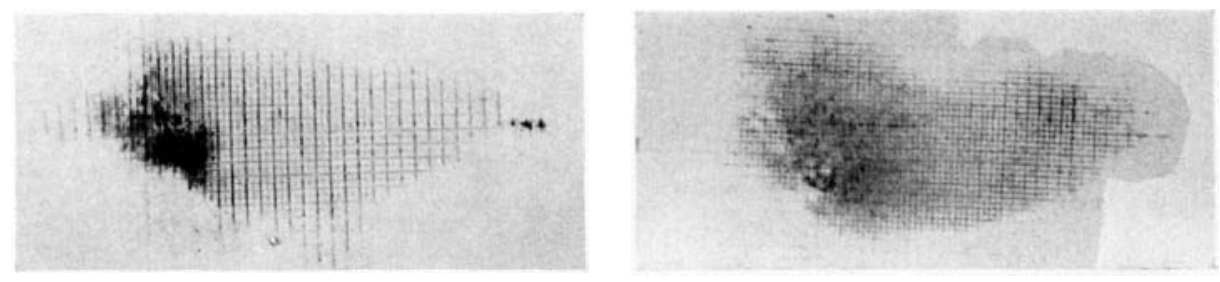

FIG. 6. Prẹ- and post-operative footprint of a patient with a fixed equinous showing changes after triple arthrodesis and tendo-achilles lengthening. 
2. Deformities due to paralysis of the posterior-tibial nerve. 'This nerve carries the motor fibres for the four layers of intrinsic muscles on the plantar aspect of the foot. Some of these muscles flex the proximal phalanges of the toes and paralysis of them results in clawing. Some degree of clawing is almost universal in patients with feet that have been shod since childhood and gives rise to increased pressure under the metatarsal heads, but it is extremely uncommon in habitually unshod feet. In a personal series of walking footprints taken from 6o normal adults who habitually walk bare-footed no case of clawing was found and the only cases with any localization of pressure under metatarsal heads were those with a congenital retraction of the $5^{\text {th }}$
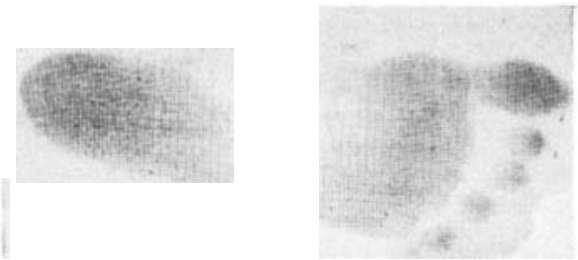

FIG. 7. Footprint of a normal habitually unshod foot. toc (Fig. 7). DUCHense pointed out that the principal action of the toc extensors is on the proximal phalanges whereas the flexors act the most strongly on the two distal phalanges. Balance is maintained by the action of the in trinsics which are flexors of the proximal phalanges and extensors of the others. When the intrinsics are weak or paralysed the proximal phalanges are hyper-extended and the others flexed (LELIÉVRE) (Fig. 8a). HICKs drew attention to the fact that the plantar fascia is attached at its anterior end to the bases of the proximal phalanges with a result that when the proximal phalanges are hyperextended increased tension is set up in the fascia; the plantar fascia is completely inelastic so that the result is to shorten the distance between the metatarsal heads and the Os Calcis (Fig. 9). The plantar fascia forms the hypothenuse of a triangle of which one of the other two sides is formed by
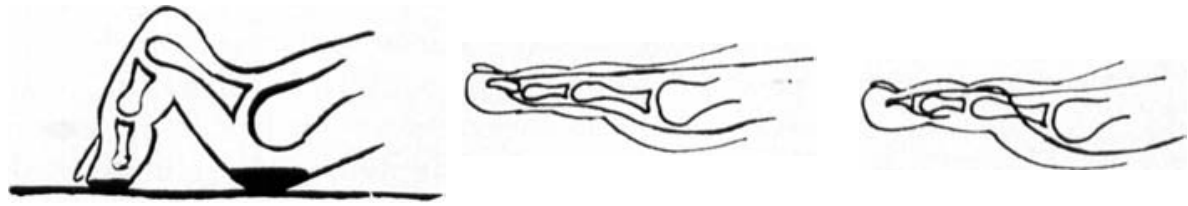

FIG. 8a. Diagram of a claw toe (after Leliévre).

FIG. 8b. Diagram to show operation for claw toe correction.
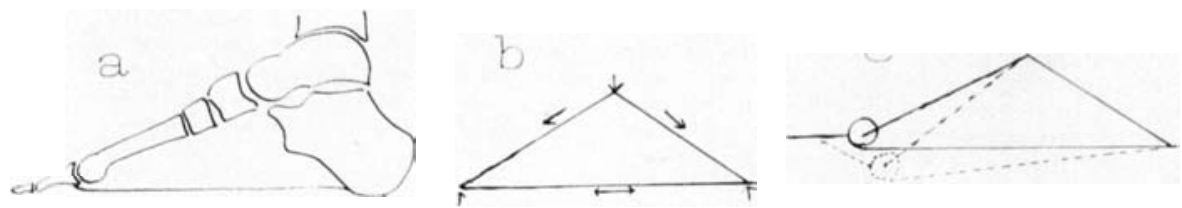

FI(i. 9. (a) 'l'he plantar fascia. (b) 'T'he foot as a triangle of forces. (c) 'T'he windlass effect. 


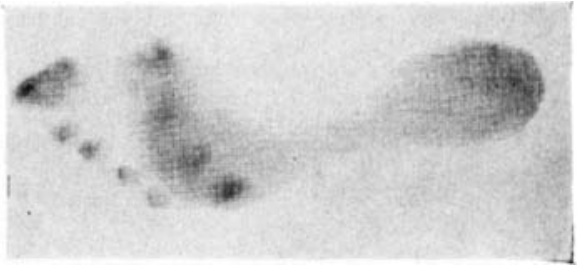

FI(i. Io a. Walking footprint of one of us (W.F.R.).

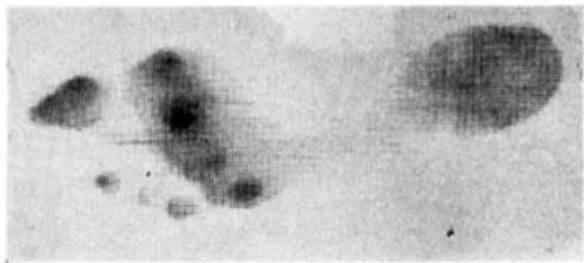

b. Walking footprint of the same foot after the second toe had been strapped into a position of dorsi-flexion.

the (Os Calcis and the 'Talus and the other by the Navicular, the Cuniform and the Metatarsal bones. 'The result of shortening the hypotenuse is a decrease in the angle between the other two sides. The position of the apex of the triangle is fixed by virtue of the body weight pressing down on it. The position of the posterior angle is also fixed for the same reason so that the only movement which can take place is a downward movement of the anterior angle which represents the metatarsal heads. That this takes place can be confirmed by holding a finger under the metatarsal heads of a normal foot and strongly dorsiflexing one of the toes (Fig. Io). Besides resulting in increased weight bearing under metatarsal heads clawing also places the tissues of the fore-foot under tension. This considerably reduces their resilience and their resistance to trauma. The increased trauma due to clawing ( $\mathrm{Fig} .8 \mathrm{a}$ ) results in ulceration in many cases and the clawing should be corrected if possible before ulceration occurs. The choice of operative procedure depends on five factors.

( I) The degree of clawing.

(2) The range of movement in the interphalangeal joints.

(3) The degree of damage already existing in the fore-foot.

(4) 'The presence, or absence, of other deformities.

(5) The particular toe or toes which exhibit clawing.

\section{OPERATIVE PROCEDURES}

\section{( I) For Mobile Cilaw Toes}

In all cases with mobile toes and relatively minor skin damage an active correction by transposition of the flexor digitorum longus on to the dorsum of the proximal phalanx is adequate (Fig. 8b). This operation is not suitable for correction of clawing of the hallux and in all cases if this digit is clawed it should be treated by fusion of the I.P. Joint (Fig. I I).

\section{(2) Rigid Cilaw Toes}

(a) With the fore-foot relatively intact. In these cases the brunt of the trauma has fallen on to the tips of the toes and the fore-foot is relatively undamaged. Fusion of the I.P. joints of the toes is recommended.

(b) With the fore-foot scarred. In cases where the scarring is limited to the skin and there is little or no damage to the subcutaneous tissue the 
286

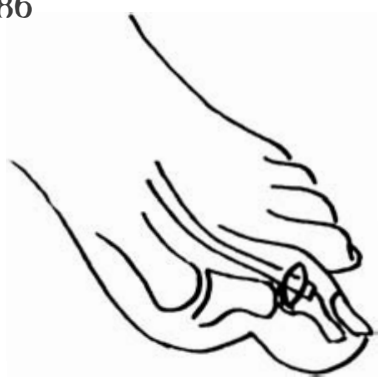

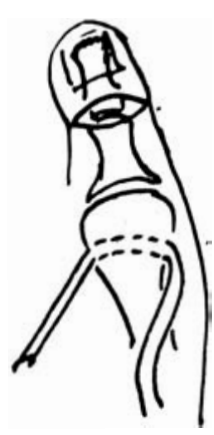

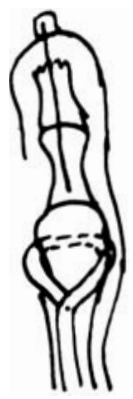

FIti. II. Jones' correction of clawing of the great toe (redrawn from I)uvries' surgery of the foot).
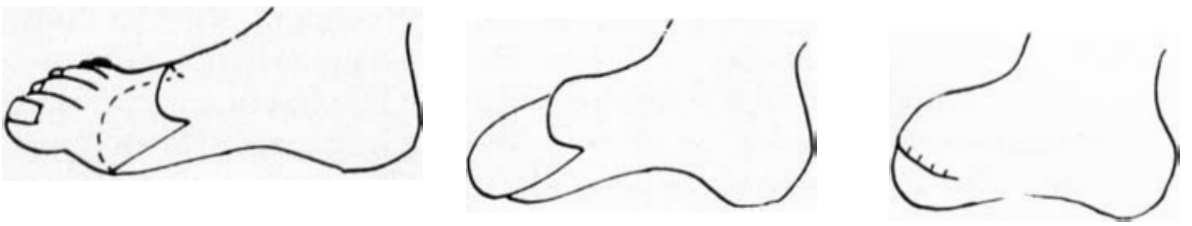

FIG. 12. Forefoot amputation redrawn from Lewin 'The Foot and Ankle'.
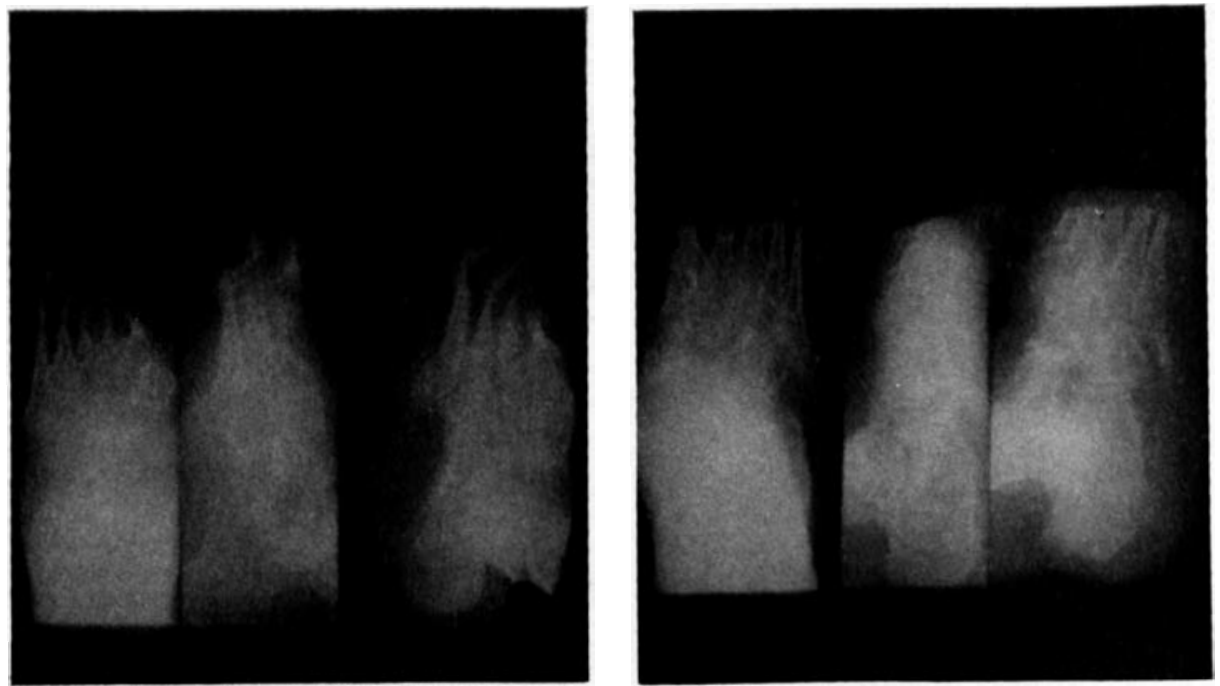

FIG. 13. X-ray to show pre- and post-operative findings in a case of fore-foot amputation (case 4).
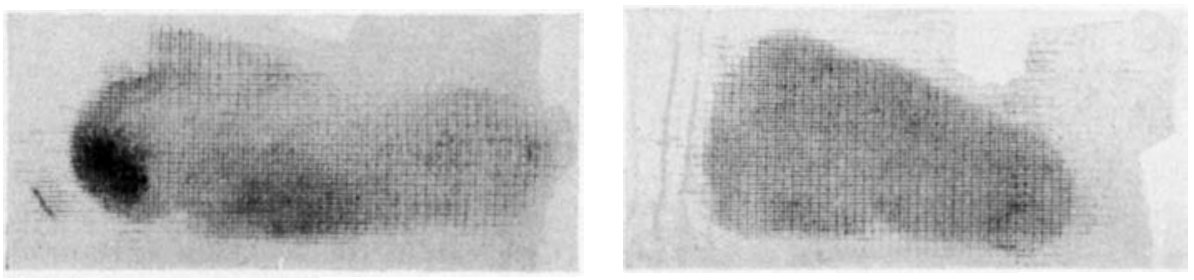

FIG. I4. Pre- and post-operative footprints in a case of fore-foot amputation. 


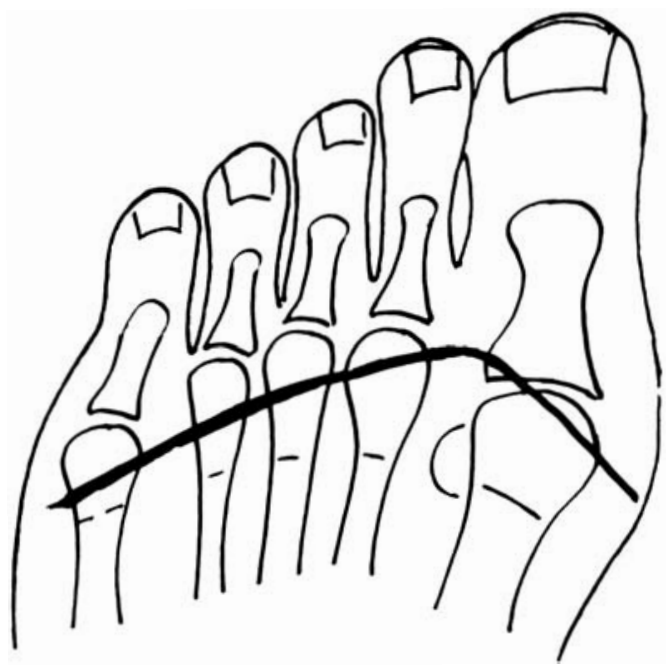

Fl(i. 15. Resection of metatarsal heads-Hoffmann's operation (after Clayton).
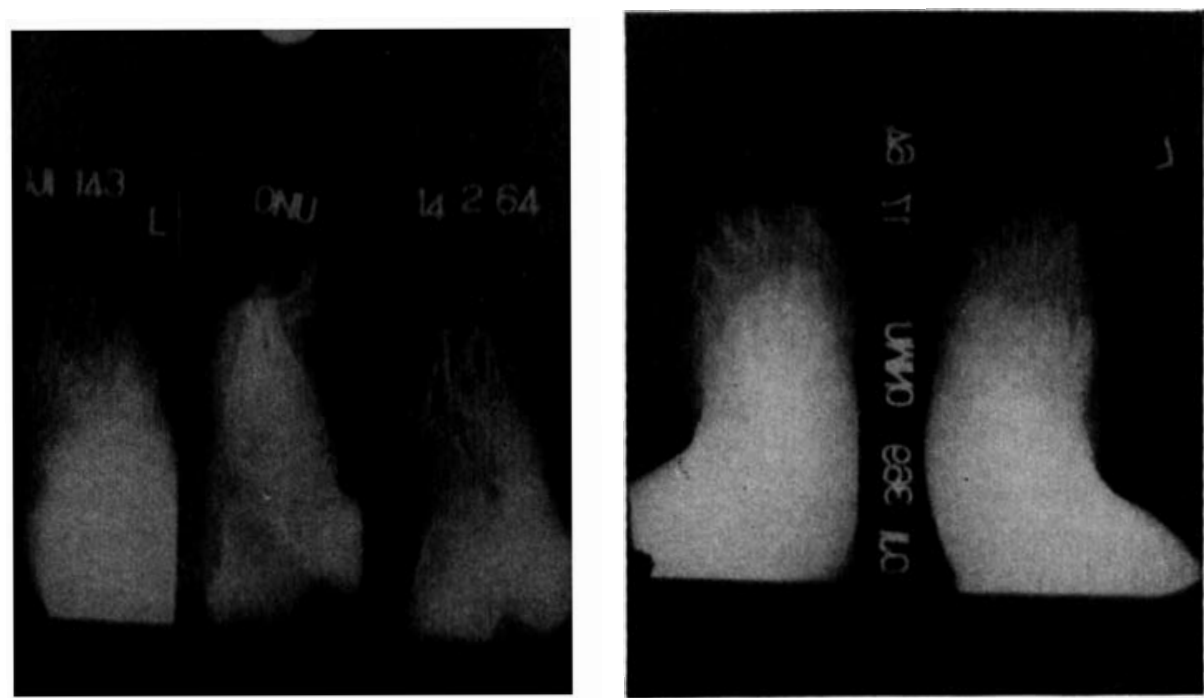

FIc. I6. X-ray to show pre- and post-operative findings in a case submitted to Hoffman's operation.
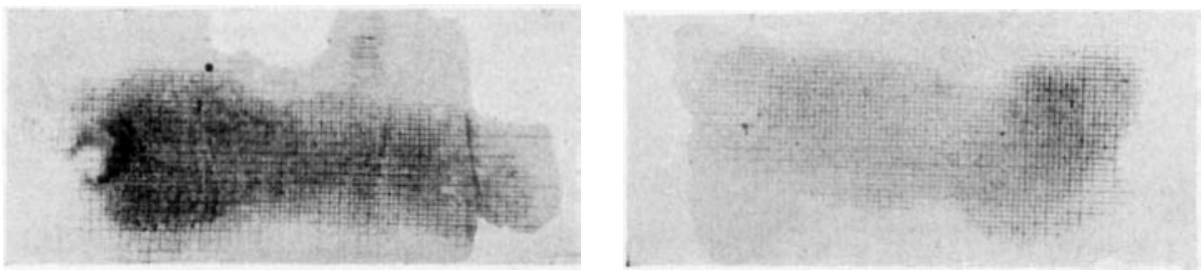

FIG. 17. Pre- and post-operative footprints in a case of Hoffmann's operation (same case as was used for Fig. I6). 
procedures described above together with the provision of resilient soled footwear will be adequate. Wherever there is more severe scarring with loss of subcutaneous tissue and damage to the underlying metatarsal heads there is no doubt that the most satisfictory procedure, where more than one metatarsal head is involved, is amputation of the fore-foot proximal to the metatarsal heads (GAss) (Figs. I 2, I 3 and I4). 'This operation gives a short well padded foot which is easy to fit with shoes and which is most unlikely to re-ulcerate. Indeed, most I.eproseria contain a few patients in whom this has happened 'spontancously' as a result of recurring ulceration and who, once the toes have disappeared and the metatarsal heads have been absorbed remain ulcer free. Unfortunately many patients are reluctant to submit to fore-foot amputation but we have found that a useful substitute is resection of all the metatarsal heads through a dorsal transverse incision (Figs. I5, I6 and I7). Patients like to retain their toes for aesthetic and, no doubt, deep psychological reasons but from a lunctional point of view the toes in these cases are useless and from the shoe workshop's point of view they are nothing but a nuisance. Nevertheless, the result of the operation if properly done in terms of freedom from subsequent ulcers is very gratifying.

(c) Proximal phalanges grossly hyperextended, fore-foot relatively intact. In these cases excision of the proximal phalanges of toes 2 to 5 through a plantar incision is the procedure of choice (Fig. I8).
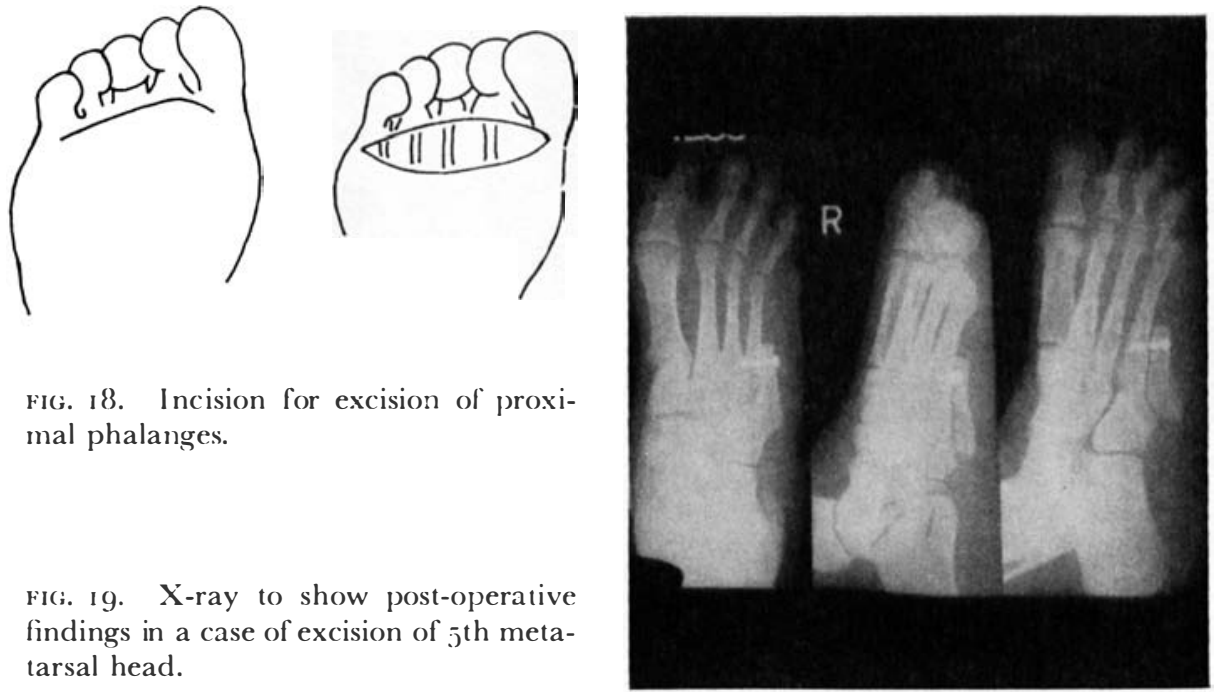

FIG. I8. Incision for excision of proximal phalanges.

FI(i. 19. X-ray to show post-operative findings in a case of excision of 5 th metatarsal head.

\section{(3) Ulceration and Scarring limited to one Toe only}

(a) Hallux. 'The ist metatarsal head alone should almost never be removed. If it is quite impossible to prevent re-ulceration under the hallux with footwear on account of the poor quality of the scar then all the metatarsal heads should be excised. 
(b) 'The $5^{\text {th }}$ Metatarsal Head. 'This metatarsal head can be removed without seriously damaging the foot but it is recommended that the metatarsal should be cut off quite short or else re-ulceration is likely at the tip of the metatarsal stump (Fig. 19).

(c) Heads 2-4. Where one of the other metatarsal heads is involved DUVRIE.s' operation which involves removal of part of the head and implantation of the long extensor tendon into the neck of the metatarsal has been found very satisfactory (Figs. 20 and $2 \mathrm{I}$ ).
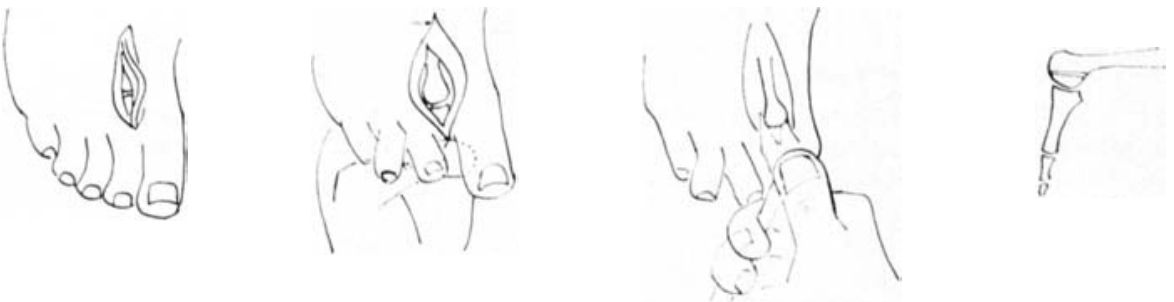

FIG. 2). Duvries' operation for partial removal of metatarsal head (from surgery of the foot by Duvries).
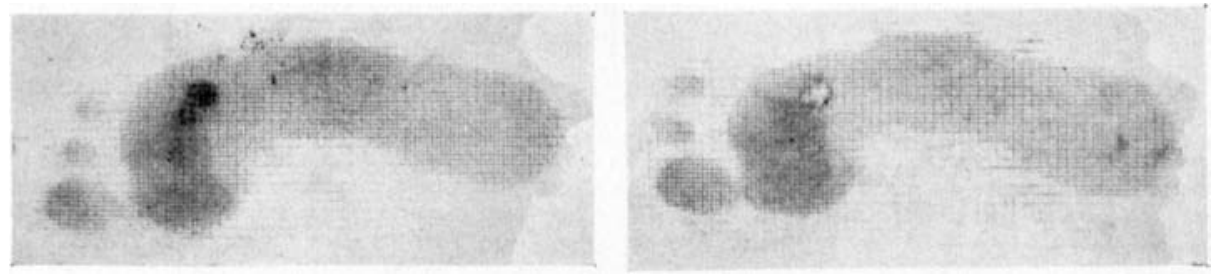

FIG. 2I. Pre- and post-operative footprints in a case of Duvries' operation (case 22).

\section{(4) Ulceration not Associated with Specific Deformities}

(a) Proximal Phalanx of Hallux. A high proportion of normal individuals' weight bear on the proximal phalanx of the hallux (Fig. 8) and in some leprosy patients this results in ulceration and scarring. In my experience the only way to prevent re-ulceration in all cases, except those in which the skin only is involved, and these are very rare for usually the long flexor tendon is destroyed at the time of the ist ulcer, is to excise the proximal phalanx leaving its base intact. A more satisfactory procedure is to amputate the toe, again, leaving the base of the proximal phalanx in position.

(b) Hecl Ulcers. Fortunately the majority of heel ulcers are not associated with calcaneal involvement and will remained healed if the patient is provided with resilient soled footwear. If X-rays are taken many patients with heel ulcers show a calcaneal spur but unless it is clear that this spur is related to the site of the ulcer, and in most cases it is not, it should be left alone. If the spur is related to the site of the ulcer then it may be removed through a hecl flap. This operation necds to be done 
very carefully and the flap must be dissected subperiostally in order to conserve the structure of the heel pad. In the few cases in which there is gross osteomyelitis of the calcaneum or in which a thin scar becomes lixed to the calcancum amputation must be resorted to. In selected cases use can be made of the dorsal skin of the foot to form a flap to cover the end of the stump.

\section{NOTHS ON OPERATIVE THECHNIQIFES}

(omplete and slightly different accounts of these procedures can be found in the references given.

(1) Tibialis Posterion Trans/nesilion. 'This is the procedure of choice for correction of loot-drop and the inversion associated with it. It should be noted that it is the inversion component of the foot-drop which is most dangerous. 'T he aim of the operation, therefore, must be primarily correction of the inversion. 'The correction of the foot-clrop is almost
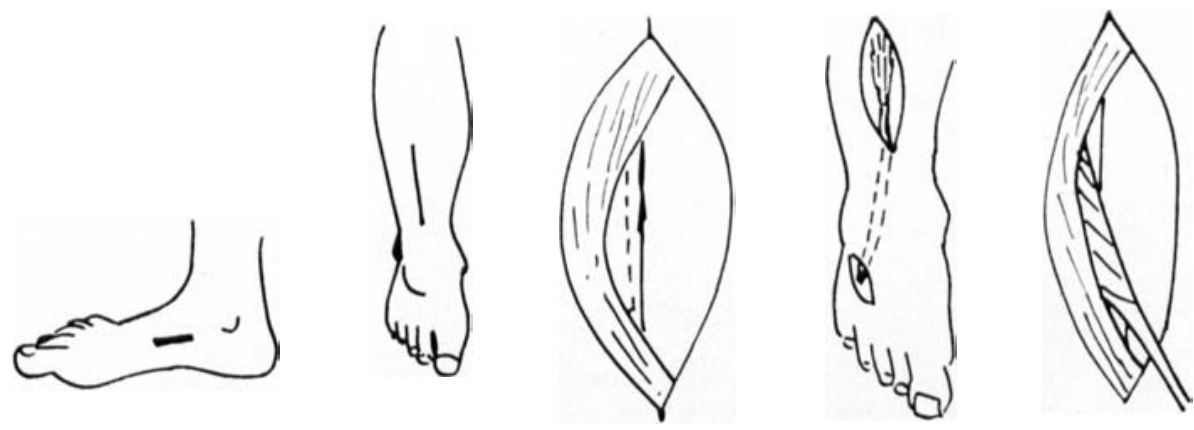

FIG. 22. Anterior transposition of the tibialis posterior, interosseous route. (Modified from Leléivre.)
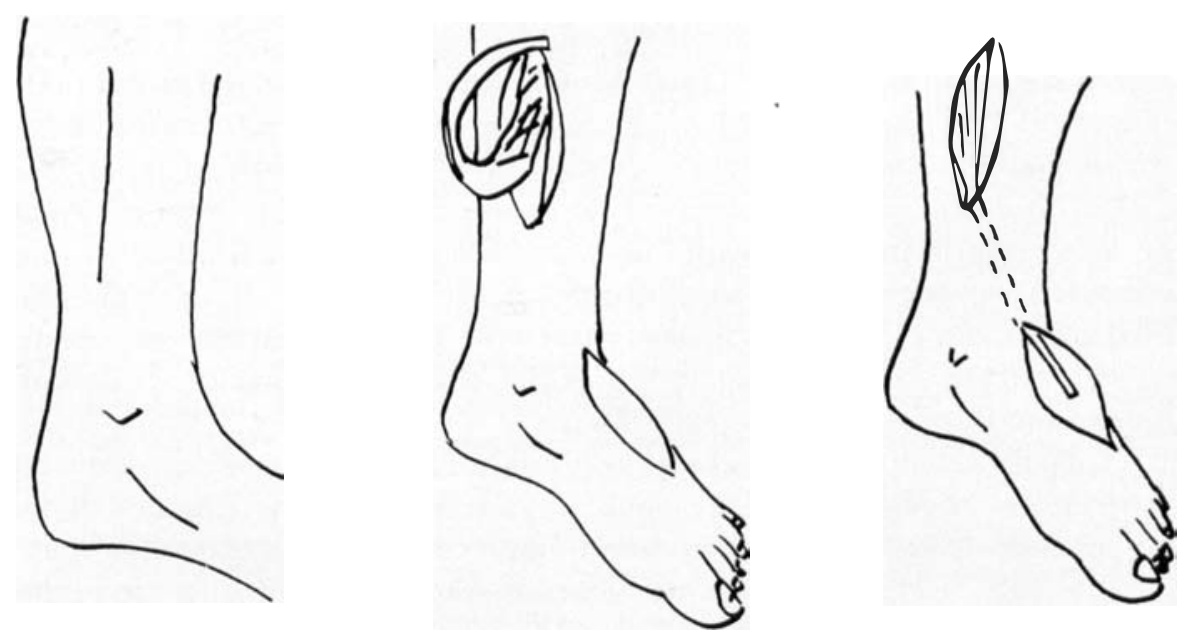

FI(i. 23. Anterior transposition of the tibialis posterior, circumtibial route. (Modified (rom L.ewin.) 
incidental. Fortunately the 'libialis Posterior is never affected in leprosy and is always available for transposition. 'The basis of the procedure is to divide the 'libialis Posterior tendon at or near its insertion in the tubercle of the navicular and to re-route the tendon so that it crosses the ankle in front of the axis of the joint and to re-insert it on to the dorsum of the foot. (Figs. 22, 23.) 'The muscle in its normal site is a plantar flexor and inverter of the foot (Fig. 4) and in its new position is used as an everter and dorsiflexor. Considerable re-education is, therefore, necessary and this must begin pre-operatively. 'The patient must be taught to isolate the muscle and learn to contract it without contracting the calf muscles at the same time. Re-education is not easy pre-operatively. Post-operatively it may prove impossible. Provided the patient can isolate the muscle exercises designed to strengthen it are usually not necessary. 'The range of movement of the ankle joint should also be measured pre-operatively. If with the knee flexed the foot (annot be dorsiflexed to at least $75^{\circ}$ a tendo-achilles lengthening will be required. lixperience has shown that for patients with simple unheeled shoes the best range of movement of the ankle is from $85^{\circ} 1095^{\circ}$. As approximately $10^{\circ}$ of dorsiflexion is lost during the post-operative period in the average (ase it is necessary to set the foot up) dorsiflexed at an angle of $7: 5^{\circ}$ during the operation.

\section{Melhod of Distal Fixation of the Tendon}

'T 'The standard method of fixing the free end of the 'Tibialis Posterior tendon on to the dorsum of the foot is by bone insertion. In some cases of leprosy this has been followed by disintegration of the tarsal bones and in order to avoid this complication various forms of tendon anastomosis have been tried. None of these procedures, in my hands at least, gives as good a result as bone insertion and in patients with unstable subtaloid joints the results of procedures involving tendon anastomoses are bad. In addition tendon anastomoses are much more difficult to perform than bone insertion and finally midtarsal disintegration has been seen following such a procedure (Fig. 3). Mid-tarsal disintegration is also seen in leprosy patients with neuropathic feet who have never had surgery (PATTERSON and JOB) and it seems likely that the coincidence of operative procedures and mid-foot bone destruction is purely a fortuitous one. Bone insertion is, therefore, the procedure of choice.

\section{Re-rouling the Tibialis Posterior}

Two routes are available for the 'Tibialis Posterior to pass from the calf to the dorsum of the foot. 'The tendon may be taken either between the tibia and fibula (Fig. 22), through the interosseous space or by a circumtibial path round the medial border of the tibia (Fig. 23). In the first instance, the tibialis posterior is taken through a longitudinal incision made over the distal 1 " or $1 \frac{1}{2}$ " of the tendon. A longitudinal incision is then made over the anterior compartment extending through the middle third of the leg. 'The 'Tibialis Anterior muscle is exposed and retracted laterally together with the anterior tibial vessels and nerves. A long incision is then made in the interosseous membrane and the post-Tibial muscle will then herniate or partially herniate through the cut into the anterior tibial compartment. The tendon is then identified and withdrawn. The tendon can also be withdrawn on the lateral side of the Tibialis Anterior but in this case care must be taken not to injure the Anterior Tibial Artery and Vein. From the anterior compartment the tendon is passed subcutaneously on to the dorsum of the foot for its attachment as far lateral and distal as is convenient. I have yet to see a foot in which inversion has been over-corrected by this procedure. Before passing the tendon subcutaneously it is useful to estimate the point at which its distal end will be when it has been re-routed and site the incision on the dorsum of the foot accordingly.

Secondly, the circum-tibial route (Fig. 23). The Tibialis Posterior is taken from its distal insertion as before and a longitudinal incision about 4 " long is made just behind the medial border of the Tibia with its distal end 3 " from the medial malleolus. The Tibialia Posterior tendon is identified, withdrawn and passed subcutaneously across the front of the ankle to the lateral border of the foot. 


\section{Method of Insertion}

The best method of insertion is to make a hole in one of the lateral bones of the foot in such a position that when the foot is fully doriflexed and everted and the tendon is taut the end of the tendon will snug down into the hole. 'The tendon can be fixed in position best by a pull out wire.

(2) Claw Toe Ciorrection. 'l'oes 2-5. 'T'hrough a long dorsi-lateral incision which curvesat its base onto the dorsum of the toe the Flexor tendon sheath is exposed and opened. 'The long Flexor tendon is taken near its insertion and withdrawn (Fig. Io). 'The skin is then retracted laterally so as to expose the Extensor tendon. 'The Long Flexor is threaded through the Extensor on the dorsum of the proximal phalanx and is then taken across the proximal inter-phalangeal joint and again threaded through the Long Illexor. It is sutured in this position with the I.P. Joint as near straight as possible with the tendon under full tension and with the ankle plantar flexed. Post-operatively the foot is immobilized in a below-knee plaster of Paris case with the ankle in neutral position for four weeks. 'This operation may sound a rather drastic procedure for claw toe correction but in fact we have yet to see a toe over-corrected by this method and have found that to anastomose the Long Flexor to the lateral band of the dorsal expansion is not adequate.

(3) Excision of proximal phalanges. Proximal phalanges of toes $2-5$ can be quite easily excised through a plantar incision across the bases of these four toes (Fig. 18). 'I 'he incision opens onto the middle of the proximal phalanx and from here the phalanges can be dissected out sub-periostially without interfering with the sub-cutaneous tissue at all. Using this incision it is of ten possible to determine by inspection that the base of the proximal phalanx is in some cases more closely related to the site of ulceration than is the metatarsal head.

(4) Metalarsal Head Resection. 'The object of this procedure is to shorten the metatarsals so that their proximal ends are behind the scarred area of the foot. The metatarsal heads can also be resected through a plantar incision at the base of the toes but we have found that the increased dissection necessary to remove the metatarsal heads sometimes leads to damage to the subcutaneous tissue under them. It is, therefore, recommended that metatarsal heads should be removed through a dorsal incision (Fig. 15). A slightly curved incision is made across the fore-foot over the metatarsal heads. And the flap so formed retracted. Longitudinal incisions are then made over each metatarsal head in turn. And the head and necks dissected out sub-periostially. It is easiest to begin at the 2nd metatarsal head and then proceed to the ist and to the others in turn. 'The metatarsals must be shortened sufficiently to ensure that the new end of the metatarsal is proximal to the scarred area on the fore-foot. Care must be taken to see that the metatarsals are lined up in an even curve at the end of the procedure and that the underside of the cut bone is bevelled and that no fragment of loose bone remains (Fig. I6). Bases of the proximal phalanges can also be removed at the same time but this is not usually necessary. The skin is closed and the foot immobilized in a plaster of Paris cast for three weeks post-operatively.

(5) Fore-foot Amputation. In this procedure the object is to shorten the metatarsals so that their distal end comes to lie proximal to the scarred area of the fore-foot. In addition it is, of course, necessary for the suture line to lie on the dorsum of the foot so that in making the incisions the plantar flap should be approximately $1 \frac{1}{2}$ " longer than the dorsal flap (Fig. I 2, I3).

(6) Duvries' Operation (Fig. 20). 'This is the procedure of choice for dealing with the problem of one prominent metatarsal head. A longitudinal incision is made over the top of the head. The Long Extensor tendon is divided over the middle portion of the proximal phalanx and withdrawn. The incision is deepened and the metatarsal phalangeal joint opened and the head freed until by flexing the toe the metatarsal head can be 
delivered into the wound. 'The underside of the head is then trimmed off tlat. $A$ hole is drilled in the dorsum of the head from side to side and the end of the Long Flexor tendon threaded through it and sutured to itself under full tension. After closing the skin incision the foot is immobilized in plaster of Paris with the ankle at $90^{\circ}$ for four weeks.

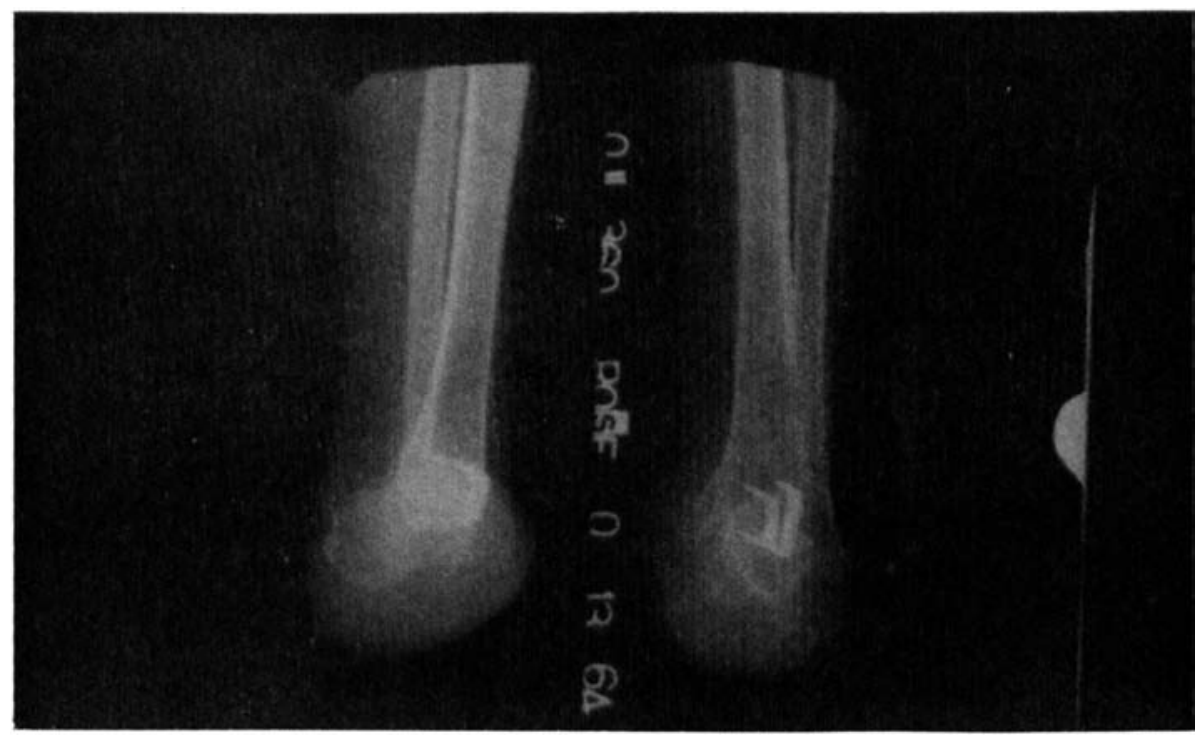

FI(. 24. X-ray in a case subjected to James' amputation.

(7) Hind-foot Amputations. 'The major areas of damage in leprosy are the fore-foot, the mid-lateral foot and the heel. So that mid-foot amputations have little if any part in the surgery of leprosy. But in cases where there is gross damage to the mid-foot it is sometimes possible to obtain an end bearing stump by hind-foot amputation. The most satisfactory stump is that given by a James' amputation in which the calcaneum is fused to the tibial mortice after excision of the talus (Fig. 24). This procedure avoids any interference with the heel pad and in cases where the heel is unscarred it is a worthwhile operation. More frequently a Symes' amputation is the only one feasible as there is often insufficient undamaged tissue to cover the calcaneum. The most important points in carrying out a Symes are (I) sub-periostial dissection of the heel pad off the calcaneum, and (2) on no account should dog-ears be trimmed. These will, in most cases, spontaneously absorb and if they do not can be excised once the wound is thoroughly healed. If the dog-ears are removed at the time of the initial operation sloughing of the heel flap is likely. For this operation to be worth while it is not necessary to have a completely intact heel pad but by varying the initial incisions and so excising scar tissue a useful if unconventionally shaped stump can be produced even from a partially scarred heel.

(8) Long Leg Ampulation. When an amputation has to be performed in our view the leg should be left as long as possible. 'Ihere are three reasons for this. Firstly, we have found it easier to fit satisfactory prosthesis to long stumps than to short ones. Secondly, a long stump enables the patient to make brief journeys on his stump, for example, at night, without having to search for his prosthesis, and thirdly, it is quite easy to shorten a stump if necessary. If the skin on the lower third of the leg is very poor or the circulation inadequate or there is some other complication such as deep venous thrombosis then, of course, amputation at a higher level is necessary. 

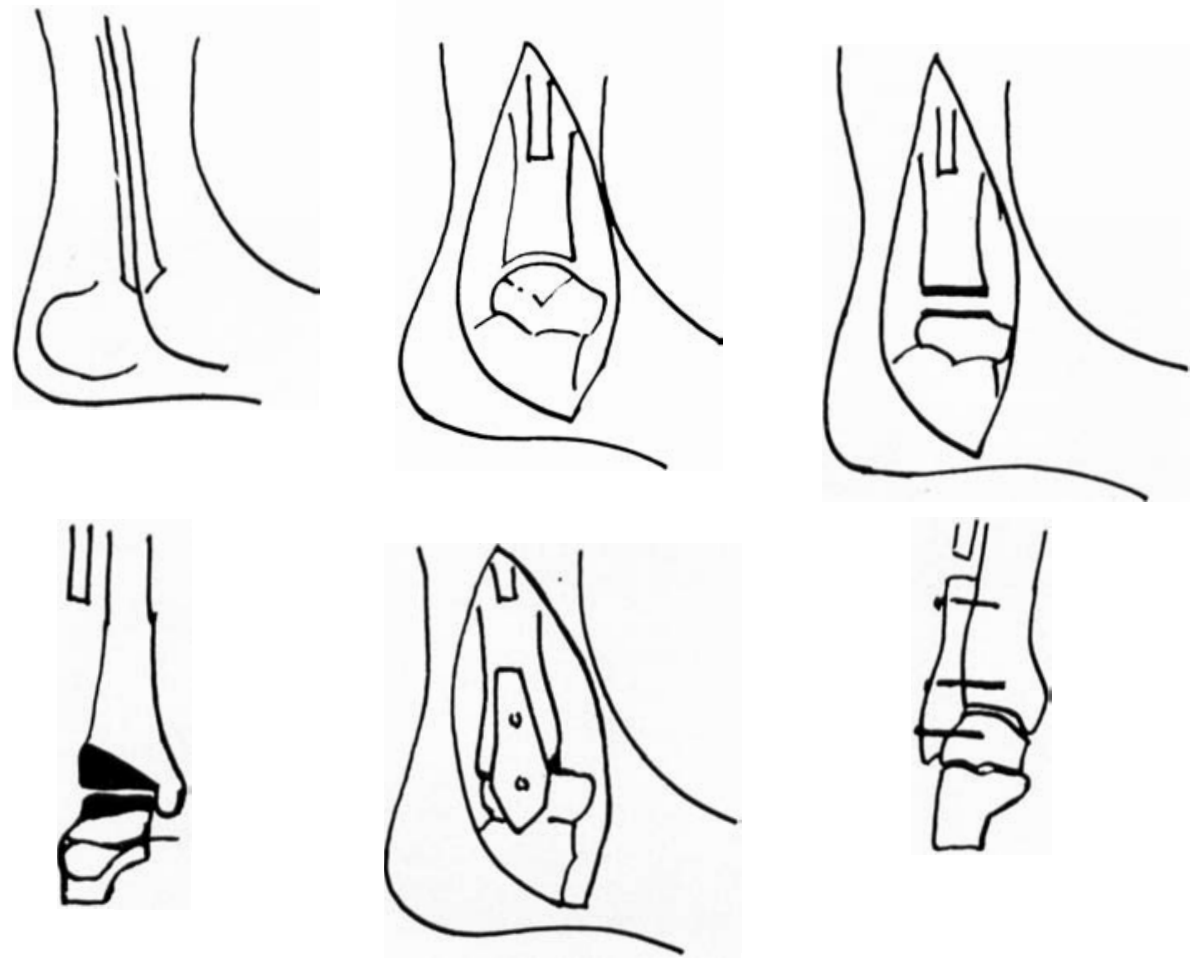

FIs. 25. Wedge resection of the ankle joint. (Modified from Leliévre.)
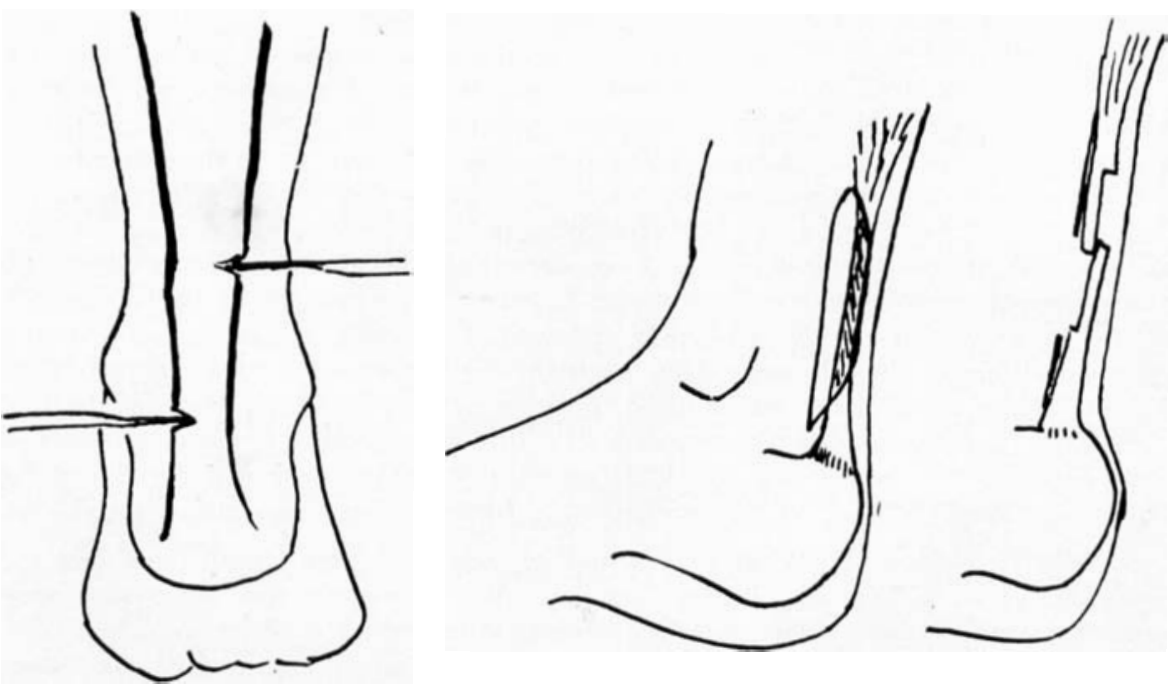

FIG. 26. Double subcutaneous tenotomy of tendo-achilles (after Lewin: The Foot and Ankle).
Fig. 27. Open operation for tendoachilles lengthening (Brand). 
(9) Sub-Taloid Arthrodesis. 'The purpose of this procedure in leprosy patients is to correct eversion. It is not recommended as a treatment for neuropathic changes in the mid-foot or hind-foot for in these cases fusion is extremely difficult to achieve and our view at present is that feet showing neuropathic changes in the bones are best left alone surgically and treated by means of prolonged bed rest. A formal triple arthrodesis is well described in standard text-books. We have not found internal fixation necessary and $12-16$ weeks immobilization post-operatively is quite adequate.

(Io) Wedge Resiction. A J-shaped incision is made along the line of the tibia with the crook of the J extending forwards just below the tip of the lateral malleolus (Figs. 5 and $25)$. The lower third of the fibula is dissected free sub-periostially and removed thus exposing the ankle joint. An adequate wedge of the joint is then taken so as to correct whatever deformities are present. 'This is usually eversion and some equinous. If it is possible to close the wound without tension the segment of fibula may be used as an onlay graft but this is not essential. After closing the wound the limb is immobilized in a below-knee plaster of Paris cast for $12-16$ weeks.

( I ) T.A. Lengthening. If a minor degree of lengthening is needed this can simply be done by subcutaneous tenotomy. More extensive lengthening requires open operation (Figs. 26 and 27).

\section{S U M M A R Y}

'l'his paper presents a series of 43 patients operated on to prevent recurrence of ulceration, in $196 \mathrm{I}-62$. Based on this, and subsequent experience, operative proceedures for dealing with specific problems are recommended and details of operative techniques which have an application to foot problems in leprosy are described.

\section{FOOTNOTE}

The M.C.R. sandals are made with a micro-cellular rubber called Sorbocel (R.B.N.F.S.) obtainable through Bata shoe company.

\section{A CKNOWLEDGEMENTS}

A. Thanks are due to Dr. AzIke, Area Superintendent, Oji River, and to Mr. IKPE, Perm. Sec. Ministry of Health, for permission to publish.

B. The authors gratefully acknowledge the very great help received from Orthopaedic Surgeons from the USA who have worked with us at Oji River, under the auspicies of Medico Inc. (Northop Project).

\section{References}

i. bauman, J. H., girling, J. P., and brand, P. w. Plantar Pressure and Trophic Ulceration. An Evaluation of Footwear. 7. Bone and Joint Surgery, 45B, 652-673.

2. Clawson, D. K., and seddon, H. J. The Late Consequences of Sciatic Nerve Injury. Ibid. $42 \mathrm{~B}, 213$.

3. harris, R. I., and вEAth, T. Canadian Army Foot Survey National Research Council of Canada.

4. HICks, J. H. The Mechanics of the Foot. II. 'The Plantar Aponeurosis and the Arch. J. Anat., 88, 25-30.

5. Paterson, D. E., and Job, с. к. Chapter XXVI, Leprosy in Theory and Practice. Cochrane and DAVEY (2nd Edition). John Wright \& Sons, Bristol.

6. Richards, R. I. Vasomotor and Nutritional Disturbances after Injury of Peripheral Nerves. Peripheral Nerve Injuries. Medical Research Council, pp. 25-56.

7. PRICE, E. w. Studies in Plantar Ulcers in Ieprosy. Leprosy Review, 30 and $3 \mathbf{1}$. 
8. Ross, w. F. Footwear and the Prevention of Ulcers in I.eprosy. Leprosy Review, 33, 202-206. 9. WARI), 1. J. Footwear in Leprosy. Leprosy Review, 32, 94.

Io. (iAss, H. н. (1938). 'A Study of the Results of Ciertain Surgical Procedures in Leprosy' Proceedings of Cairo Conference (1938).

\section{Standard Texts}

I. cochrane, R. G., and Davey, T. F. Leprosy in Theory and Practice (2nd Edition), Chapters XXVII, XXIX and XXX. John Wright \& Sons, Bristol.

2. Duvries, H. 1.. Surgery of the Foot. The C.V. Mosby Company, St. I.ouis.

3. 1.EWin, P. The Foot and Ankle. Henry Kimpton, London.

4. t.mitévre, J. Pathologie du Pied. Maison et Cie, Paris.

\section{Special Texts}

I. loot-drop) and (law The correction.

PRITSCHI, E. P., and bRANI), P. W. 'The Place of Reconstructive Surgery in the Prevention of Foot Ulceration in I.eprosy. International Journal of Leprosy, vol. 25, 1.

2. Metatarsal Head Resection.

CI.AYTON, M. 1.. Surgery of the forefoot in Rheumatoid Arthritis. Cilinical Orthopardics, 16, $136-140$ ). uoliman, P. An Operation for Severe (srades of Contracted or Clawed Toes. Am. 7. Orthop. Surg., 9, 441, I9)11. 